\title{
Trend Analysis of Temperature: A Case Study of Aegean Region, Turkey
}

\author{
Bacanlı U.G. ${ }^{1}$, Tanrıkulu A. ${ }^{2}$
}

\begin{abstract}
Climate change was expected to have great impacts. The effects of climate change have direct implications on temperature regimes. The aim objective of this study was to investigate the trends of monthly and annual mean temperature datas of Aegean Region in Turkey. For this purpose used the 35 stations. These data sets were trend analyzed.To determine trends of datas non-parametric Mann-Kendall, Spearman Rho, Sen method and parametric linear regression methods were used.The difference in monthly and annual changes were examined. Annual average temperature analyzes showed an increasing tendency in general, with an average trend of $85 \%$ in all methods. Monthly average temperature analyzes showed increasing temperature trends in May, June, July, August, September and October. In generaly, no significant trends have been observed outside of these months. The average rate of increase in ownership among these stations is $71 \%$. Results of the temperature data trend show a general increasing trend. This results were indicator of effects of climate change and drought in Aegean Region. After the operating, managing and planning of water resources in the region should be taken into consideration of this effects of climate change and drought.
\end{abstract}

Keywords: Linear regression, Mann-Kendall, Precipitation, Sen's, Temperature, Trend analysis, Turkey

\section{Introduction}

Continuously increasing human activities affect the composition of the atmosphere to a significant extent. The sensitivity of Earth's climate depends on the future greenhouse-gas-induced warming.The increasing of concentration of the long-lived greenhouse gases in the atmosphere leads to global warming (Friedli et al., 1986; Lorius et al., 1990). The effects of global warming are evident from observations of increases in global average air and ocean temperatures (Viola et al., 2014).Global surface temperature has increased by about $0.3-0.6^{\circ} \mathrm{C}$ since the late 19th century and about $0.2-0.3^{\circ} \mathrm{C}$ over the last 40 years in the 20th century (Houghton et al., 1995).

Local and regional long-term temperature records are used in climate variability investigations. Trends analysis becomes the most commonly used technique to represent the effect of the climate variability in regional and local basis (Kadioglu, 1997).In climate assessment studies, trends are statistical fundamental tools in the detection of climate variability. In the regarding the analysis of temperature trends present from past to present many studies have been carried out and maintained.Some of these are as follows.

Karl et al. (1993) analysed monthly mean maximum and minimum temperatures from countries comprising $37 \%$ of the global landmass. They found that the minimum temperature increased over the period $1951-1990$ by $0.84^{\circ} \mathrm{C}$ $\left(0.56^{\circ} \mathrm{C}\right)$ compared to only $0.28^{\circ} \mathrm{C}\left(0.33^{\circ} \mathrm{C}\right)$ increase in maximum temperatures.Kruger and Shongwe (2004) studied trends in South African temperaturesfor the period 1960 to 2003. A total of 23 stations showed positive trends in their annual mean maximum temperature series. Monthly trends of average annual temperatures showed large differences in trend between stations, and for each station between months, but similar tendencies in trend between months were found to exist for stations closeby and also for groups of stations on a regional basis.Daily maximum and minimum temperatures, Tmax and Tmin, and diurnal temperature range, DTR, are analyzed to detect significant daily time trends for the period 1975-2004for 37 temperature stations in Catalonia (NE Spain)by Serra et al. (2010). The results indicated generalized increasing annual trends of daily Tmax andTmin $\left(0.5{ }^{\circ} \mathrm{C} /\right.$ decade $)$. Severalperiods with an outstanding number of stations showing significant positive time trends are detected and analyzed duringthe spring and summer seasons both for daily Tmax and Tmin. The only period with a relevant number of significantnegative trends is detected in February for daily Tmin, thus implying a significant increasing trend of DTR during this shortwinter period.Trends in daily maximum and minimum extreme temperature indices have been analysed for 28 weather stations in South Africa byKruger and Sekele (2012). The general result observed that warm extremes increased and cold extremes decreased for all of the weather stations. However trends varied on a regional basis, both in magnitude and statistical significance.Safeeq et al. (2013) examined trends in minimum and maximum temperatures in the Oahu-Hawaii during the period of past 39(1969-2007) and 25 (1983-2007) years. Trend in diurnal temperature range (DTR) showed a decline during the past 39 years with a stronger decreasingtrend during the recent 25 years. Extreme temperature indices showed a general warming during the past 39 years. There has been significant increase in tropical and warm nights at the two urban stations. Trends in maximum temperature (Tmax), minimum temperature (Tmin) and mean temperature (Tmean) have been analysed from 1961 to 2004 for 35 stations in the Godavari River basin in Southern Peninsular India by Jhajharia et al.(2013). About $60 \%$ (45\%) of the stations exhibited increasing trends in Tmax (Tmin) in different durations. Results of tests of spatial and temporal homogeneity of trends by the Van Belle and Hughes method showed that trends in temperature over the Godavari basin were not homogeneous for different months or at different stations.Almazroui etal. examined on 13 annual extreme indices for Saudi Arabia, using observations from 27 surface stations with high-quality data for the period 1981-2010. The findings show that $92 / 89 \%$ of the stations displayed a significant increase in the annual occurrence of warm days/nights and 96/93\% revealed a significant decrease for the occurrence of cool days/nights (Almazroui etal., 2014). Panda and Kumar (2014) analysed trends in monthly, seasonal, and annual rainfall and

\section{Volume 6 Issue 7, July 2017 www.ijsr.net}




\section{International Journal of Science and Research (IJSR) \\ ISSN (Online): 2319-7064}

Index Copernicus Value (2015): 78.96 | Impact Factor (2015): 6.391

temperature on the subdivision and regional scale for the northeast India. Trend analysis of rainfall data series for 1871-2008 did not show any clear trend for the region as a whole, although there are seasonal trends for some seasons and for some hydro-meteorological subdivisions. Similar analysis for temperature data showed that all the four temperature variables (maximum, minimum, and mean temperatures and temperature range) had rising trend.

In this study, the temperature in the35stations of the Aegean Region for the period of the longest period1950-2015 and the shortest period 1971-2015 were analyzed statistically in different time series including averages of yearlyand monthly pattern. These data sets were trend analyzed by using linear regression analysis, Mann-Kendal, Rho and Sen's methods. The difference in monthly and annual changes were examined. The work to be done here will provide significant contributions to the water resources of this region which are important for Turkey as agricultural.

\section{Study Area and Data}

The Aegean region extends over an area of approximate $85.000 \mathrm{~km}^{2}$, which is nearly $11 \%$ of the total geographical area of Turkey. The Aegean Region is one of the 7 geographical regions of Turkey. It is bordered by the Aegean Sea andlocated in western Turkey (Figure 1). The Aegean coastal plain has an exceptionally mild climate. The Aegean region has perpendicular mountains to its shores and many valleys between them. Although some of the provinces inland show also characteristics of continental climate (Erinç, 1957; Bacanli, 2011).

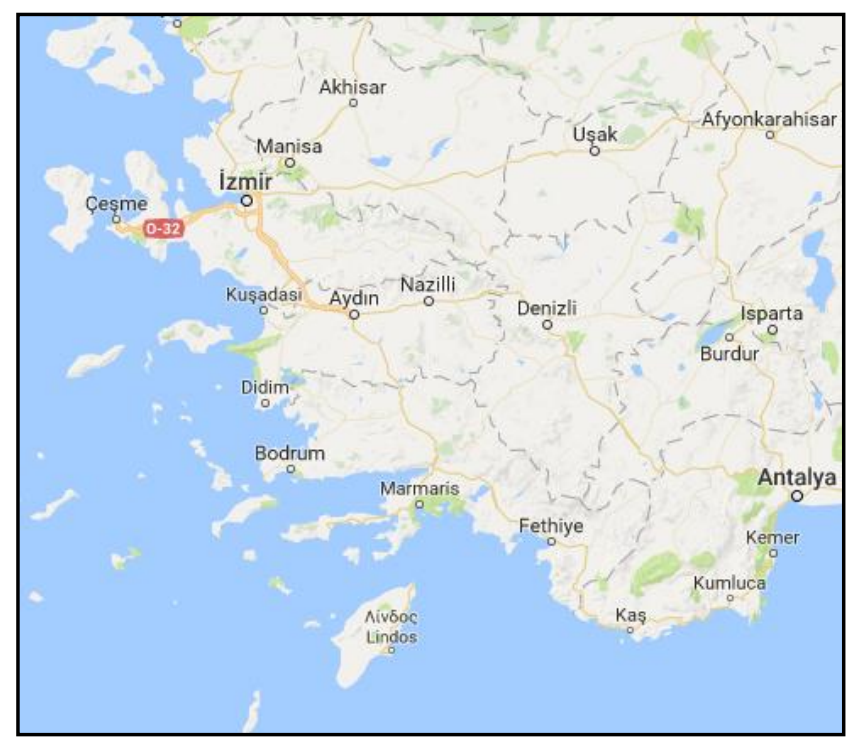

Figure 1: Aegean Region

The dataset used in this study includes annual and monthly (Tmean) temperature variable, recorded at 35 stations of the TurkishState Meteorological Service (TSMS) over the longest period1950-2015 (Table 1).Missing temperature data at a station for time periodwere filled by the average values of the nearest stations. Monthly average data of Tmean of all the 35 stations of the Aegean region are given in Table 2, which shows that the average mean temperature varies from $0.06^{0} \mathrm{C}$ at Bolvadin the month of January to $28.79^{\circ} \mathrm{C}$ at Milas in the month of July (DMI).

Table 1: Raingauge Stations in the Aegean Regions

\begin{tabular}{|c|c|c|c|c|c|c|c|c|}
\hline \multirow{2}{*}{$\begin{array}{l}\text { Station } \\
\text { Number }\end{array}$} & \multirow{2}{*}{$\begin{array}{c}\text { Station } \\
\text { Name }\end{array}$} & \multirow[b]{2}{*}{ Latitude } & \multicolumn{3}{|c|}{ Elevation } & \multicolumn{3}{|c|}{ Standart } \\
\hline & & & Longltude & $(m)$ & Period & Mean & Deviation & Skewness \\
\hline 17890 & Acıpayam & 17.4337 & 29.3498 & 941 & $1966-2015$ & 12.76 & 1.58 & -4.05 \\
\hline 17819 & Afyon & 38.738 & 30.564 & 1001.49 & $1950-2015$ & 11.36 & 0.86 & 0.66 \\
\hline 17184 & Akhlsar & 38.9118 & 27.8233 & 92.034 & $1950-2015$ & 16.28 & 0.69 & 0.21 \\
\hline 17234 & Aydın & 37.8402 & 27.8379 & 56.3 & $1950-2015$ & 17.78 & 0.58 & 0.23 \\
\hline 17742 & Berzama & 39.1098 & 27.171 & 53 & $1959-2015$ & 16.01 & 2.78 & -6.77 \\
\hline 17290 & Bodrum & 37.0328 & 27.4398 & 26.47 & $1950-2015$ & 19.19 & 0.73 & 1.93 \\
\hline 17796 & Bolvadin & 38.7268 & 31.0477 & 1018 & $1968-2015$ & 11.27 & 0.92 & 0.52 \\
\hline 18442 & Bomova & 38.5019 & 27.2692 & 400 & $1963-2015$ & 17.35 & 0.49 & 0.36 \\
\hline 17221 & Cesme & 38.3036 & 26.3724 & 5 & $1963-2015$ & 17.34 & 0.69 & 1.40 \\
\hline 17746 & D.Manisa & 39.0349 & 28.6482 & 855 & $1991-2015$ & 13.24 & 1.84 & -3.53 \\
\hline 17297 & Datca & 36.7093 & 27.6919 & 28 & $1965-2015$ & 19.56 & 0.57 & 0.49 \\
\hline 17237 & Den|z|| & 37.762 & 29.0921 & 425.29 & $1956-2015$ & 16.07 & 1.79 & -5.14 \\
\hline 17233 & Didim & 37.3699 & 27.2645 & 44 & $1996-2015$ & 18.85 & 0.62 & 0.28 \\
\hline 17180 & DIkIII & 39.0737 & 26.888 & 3.4 & $1950-2015$ & 16.60 & 0.58 & 0.27 \\
\hline 17862 & Dinar & 38.0597 & 30.1531 & 864 & $1959-2015$ & 12.55 & 1.86 & -3.27 \\
\hline 17752 & Emlrdas & 39.0098 & 31.1463 & 983 & $1963-2015$ & 11.41 & 1.37 & -3.60 \\
\hline 17296 & Fethlye & 36.6266 & 29.1238 & 3 & $1950-2015$ & 18.49 & 0.90 & 0.20 \\
\hline 17750 & Gedlz & 38.9947 & 29.4003 & 736 & $1971-2015$ & 12.52 & 1.78 & -4.62 \\
\hline 17824 & Guney & 38.1515 & 29.0587 & 825 & $1963-2015$ & 13.72 & 1.05 & -3.30 \\
\hline 17220 & Izmir & 38.3949 & 27.0819 & 28.55 & $1950-2015$ & 17.97 & 0.61 & 0.30 \\
\hline 17924 & Koyces|z & 36.97 & 28.6869 & 24 & $1959-2015$ & 18.01 & 1.60 & -3.81 \\
\hline 17232 & Kufadas! & 37.8597 & 27.2652 & 25 & $1950-2015$ & 16.72 & 2.08 & -2.81 \\
\hline 17155 & KDtahya & 39.4171 & 29.9891 & 960 & $1950-2015$ & 10.85 & 0.82 & 0.54 \\
\hline 17186 & Manlsa & 38.6153 & 27.4047 & 71 & $1950-2015$ & 17.05 & 0.58 & 0.15 \\
\hline 17884 & Milas & 37.3027 & 27.7804 & 52 & $1960-2015$ & 17.80 & 2.32 & -6.16 \\
\hline 17292 & Mu乏la & 37.2095 & 28.3668 & 646.07 & $1950-2015$ & 15.08 & 0.52 & 0.02 \\
\hline 17860 & $\mathrm{~N}$ az||I। & 37.9135 & 28.3437 & 84 & $1950-2015$ & 17.37 & 1.44 & -4.36 \\
\hline 17822 & Odemls & 38.2157 & 27.9642 & 111 & $1950-2015$ & 16.68 & 0.84 & -2.29 \\
\hline 17792 & Salln\|I & 38.4831 & 28.1234 & 111 & $1959-2015$ & 16.35 & 1.95 & -3.65 \\
\hline 17820 & Seferihlser & 38.199 & 26.835 & 22 & $1971-2015$ & 16.88 & 0.76 & 0.44 \\
\hline 17854 & Selcuk & 37.9445 & 27.3673 & 17 & $1963-2015$ & 16.60 & 0.88 & -1.12 \\
\hline 17748 & simav & 39.0925 & 28.9786 & 809 & $1959-2015$ & 11.97 & 0.82 & 0.39 \\
\hline 17704 & Tavganli & 39.5439 & 29.4917 & 833 & $1965-2015$ & 11.33 & 0.76 & 0.34 \\
\hline 17188 & Usak & 38.6712 & 29.404 & 919.22 & $1950-2015$ & 12.54 & 0.67 & -0.52 \\
\hline 17886 & Yatagan & 37.3395 & 28.1369 & 365 & $1967-2015$ & 16.39 & 0.68 & 0.73 \\
\hline
\end{tabular}

Volume 6 Issue 7, July 2017 www.ijsr.net 
International Journal of Science and Research (IJSR)

ISSN (Online): 2319-7064

Index Copernicus Value (2015): 78.96 | Impact Factor (2015): 6.391

Table 2: Monthly average data of Raingauge Stations in the Aegean Regions

\begin{tabular}{|c|c|c|c|c|c|c|c|c|c|c|c|c|}
\hline Station Name & Jan & Feb & Mar & Apr & May & Jun & July & Aug & Sep & Oct & Now & Dec \\
\hline Acıpayam & 2.18 & 3.40 & 6.78 & 11.25 & 16.21 & 20.93 & 24.51 & 24.13 & 19.51 & 13.72 & 7.60 & 3.75 \\
\hline Afyon & 0.32 & 1.65 & 5.16 & 10.27 & 14.83 & 18.89 & 21.98 & 21.70 & 17.56 & 12.06 & 6.64 & 2.33 \\
\hline Akhisar & 6.16 & 7.28 & 9.85 & 14.56 & 19.79 & 24.58 & 27.12 & 26.80 & 22.50 & 16.93 & 11.32 & 7.79 \\
\hline Aydın & 8.23 & 9.32 & 11.83 & 15.85 & 20.87 & 25.85 & 28.41 & 27.61 & 23.46 & 18.40 & 13.29 & 9.65 \\
\hline Bergama & 6.69 & 7.58 & 9.88 & 14.26 & 19.58 & 24.42 & 26.86 & 26.42 & 22.46 & 17.29 & 12.12 & 8.55 \\
\hline Bodrum & 11.40 & 11.60 & 13.25 & 16.54 & 20.89 & 25.65 & 28.24 & 28.10 & 24.56 & 20.23 & 16.14 & 12.95 \\
\hline Bolvadin & 0.06 & 1.45 & 5.35 & 10.13 & 14.94 & 19.14 & 22.58 & 22.27 & 17.72 & 12.03 & 6.20 & 2.04 \\
\hline Bornova & 8.08 & 8.67 & 10.94 & 15.11 & 20.30 & 25.38 & 27.93 & 27.22 & 22.91 & 17.99 & 12.97 & 9.85 \\
\hline Çeşme & 9.36 & 9.82 & 11.75 & 15.19 & 19.56 & 23.88 & 25.82 & 25.57 & 22.49 & 18.32 & 14.11 & 11.07 \\
\hline Datça & 12.20 & 12.29 & 13.93 & 16.73 & 20.93 & 25.29 & 27.73 & 27.91 & 25.10 & 21.00 & 16.88 & 13.81 \\
\hline D. Manisa & 3.47 & 3.92 & 6.72 & 11.38 & 16.69 & 21.06 & 24.07 & 24.50 & 19.73 & 15.11 & 9.62 & 5.38 \\
\hline Denizli & 5.90 & 6.98 & 10.11 & 14.63 & 19.76 & 24.63 & 27.50 & 26.98 & 22.36 & 16.79 & 11.40 & 7.65 \\
\hline Didim & 10.39 & 10.72 & 12.95 & 16.12 & 20.83 & 25.72 & 28.30 & 28.29 & 24.14 & 19.78 & 15.59 & 12.20 \\
\hline Dikili & 7.95 & 8.66 & 10.59 & 14.54 & 19.16 & 23.74 & 26.06 & 25.62 & 21.92 & 17.44 & 13.13 & 9.85 \\
\hline Dinar & 2.77 & 3.78 & 7.00 & 11.26 & 15.97 & 20.44 & 24.05 & 23.69 & 19.22 & 13.74 & 8.42 & 4.71 \\
\hline Gediz & 2.42 & 3.36 & 6.60 & 11.28 & 16.28 & 20.74 & 24.28 & 24.12 & 19.31 & 13.15 & 7.47 & 3.96 \\
\hline Emirdağ & 0.08 & 1.49 & 5.74 & 10.79 & 15.59 & 19.71 & 22.81 & 22.39 & 18.02 & 12.59 & 6.68 & 2.18 \\
\hline Fethiye & 10.28 & 10.99 & 13.07 & 16.32 & 20.61 & 25.16 & 27.89 & 27.84 & 24.19 & 19.34 & 14.64 & 11.58 \\
\hline İzmir & 8.86 & 9.50 & 11.69 & 15.88 & 20.80 & 25.59 & 28.03 & 27.66 & 23.64 & 18.78 & 14.00 & 10.58 \\
\hline Köyceğiz & 9.22 & 10.04 & 12.42 & 15.99 & 20.86 & 26.13 & 28.71 & 28.18 & 24.59 & 19.22 & 13.90 & 10.50 \\
\hline Kuşadası & 9.14 & 9.74 & 11.79 & 15.33 & 19.36 & 23.89 & 26.10 & 25.57 & 22.17 & 17.98 & 13.87 & 11.00 \\
\hline Kütahya & 0.57 & 1.86 & 5.16 & 10.01 & 14.59 & 18.34 & 20.89 & 20.67 & 16.58 & 11.70 & 6.74 & 2.62 \\
\hline Manisa & 6.80 & 8.08 & 10.67 & 15.26 & 20.44 & 25.44 & 28.10 & 27.76 & 23.34 & 17.81 & 12.16 & 8.44 \\
\hline Milas & 9.03 & 9.77 & 11.92 & 15.69 & 20.67 & 25.85 & 28.79 & 28.03 & 23.87 & 18.80 & 13.69 & 10.58 \\
\hline Muğla & 5.49 & 6.12 & 8.54 & 12.51 & 17.53 & 22.85 & 26.29 & 25.67 & 21.71 & 15.90 & 10.55 & 7.06 \\
\hline Nazilli & 7.37 & 8.68 & 11.59 & 16.01 & 21.26 & 26.06 & 28.75 & 27.91 & 23.53 & 18.00 & 12.45 & 8.97 \\
\hline Ödemiş & 7.16 & 8.06 & 10.74 & 14.88 & 20.00 & 25.01 & 27.73 & 27.06 & 22.45 & 16.87 & 11.91 & 8.73 \\
\hline Salihli & 6.39 & 7.52 & 10.55 & 15.27 & 20.62 & 25.23 & 27.53 & 26.87 & 22.55 & 16.92 & 11.42 & 7.93 \\
\hline Seferihisar & 8.31 & 8.81 & 10.85 & 14.51 & 19.24 & 24.19 & 26.86 & 26.42 & 22.37 & 17.65 & 13.01 & 9.89 \\
\hline Selçuk & 7.89 & 8.72 & 11.03 & 14.86 & 19.49 & 24.28 & 26.64 & 25.82 & 21.66 & 16.92 & 12.48 & 9.50 \\
\hline Simav & 2.36 & 3.17 & 6.21 & 10.67 & 15.47 & 19.46 & 22.08 & 21.71 & 17.34 & 12.38 & 7.81 & 4.41 \\
\hline Tavşanlı & 1.29 & 2.54 & 5.60 & 10.29 & 15.02 & 18.86 & 21.64 & 21.34 & 17.19 & 12.13 & 7.06 & 3.07 \\
\hline Uşak & 2.36 & 3.16 & 6.23 & 10.82 & 15.71 & 20.19 & 23.62 & 23.71 & 19.16 & 13.42 & 7.93 & 4.18 \\
\hline Yatağan & 6.72 & 7.69 & 10.19 & 14.13 & 19.16 & 24.15 & 27.47 & 26.95 & 22.53 & 16.96 & 11.56 & 7.95 \\
\hline
\end{tabular}

\section{Methodology}

\subsection{Mann-Kendall Test}

Trend in time series is controlled by zero hypothesis " $H_{0}$ : no trend" with Mann-Kendall Test which improved by Mann. The time series that will tested; $x_{i}, x_{j}$ pairs in $x_{1}, x_{2}, \ldots x_{n}$ is separated into two groups. If the number of $x_{i}<x_{j}$ pairs shown as "P" and the number of $x_{i}>x_{j}$ pairs shown as "M" for, the tests statistics ( $\mathrm{S})$ is calculated as;

$$
S=P-M
$$

The varience $(\sigma s)$ for sample number $\mathrm{n} \geq 10$ is;

$$
\sigma s=\sqrt{n(n-1)(2 n+5) / 18}
$$

After the variance has calculated, the $\mathrm{Z}$ statistic is determined.

$$
Z= \begin{cases}\frac{S-1}{\sqrt{\sigma \mathrm{s}}} & ; S>0 \\ 0 & ; S=0 \\ \frac{S+1}{\sqrt{\sigma \mathrm{s}}} & ; S<0\end{cases}
$$

The $\mathrm{Z}$ tests statistic which defined in (3) equation is a standard normal distribution. If there are equal observation, in the sample,

$$
\sigma \mathrm{s}=\sqrt{\left[n(n-1)(2 n+5)-\sum_{i} t_{i}\left(t_{i}-1\right)\left(2 t_{i}+5\right)\right] / 18}
$$

In this equation, ti shows the number of equal observation. If absolute value of $\mathrm{Z}$ that calculated as the description is lesser than the normal distribution $Z_{\alpha / 2}$ who goes against the chosen level of significance, the zero hypothesis is accepted, and there isn't trend in inspected time series; if it's greater; there is a trend and according to it;if value of $S$ is positive, there is an increasing trend and if it's negative, there is a decreasing trend.

\subsection{Theil-Sen Estimator}

If there is a linear trend in the time series, the real trend (the variation in the unit of time) can determined by using nonparametric method. This method can be used for the incomplete data records that don't affected by data error or extreme values. $x_{j}$ and $x_{k}$ are data in the $\mathrm{j}$ and $\mathrm{k}$ time (on condition that $\mathrm{j}>\mathrm{k})$

$N=n(n-1) / 2$ number $Q_{i}(\mathrm{i}=1,2, \ldots, \mathrm{N})$ Value is calculated as below.

$$
Q_{i}=\left(x_{j}-x_{k}\right) /(j-k)
$$

$\mathrm{N}$ shows the number of time periods. All $Q_{i}$ values are calculated and lined up from lesser to greater with the help of the formula above. Median of $\mathrm{n} Q_{i}$ values are a parameter to estimate the direction of the Sen Estimator trend. If $\mathrm{N}$ is a 


\section{International Journal of Science and Research (IJSR) \\ ISSN (Online): 2319-7064}

Index Copernicus Value (2015): 78.96 | Impact Factor (2015): 6.391

odd number, (6) formule is used; if $\mathrm{N}$ is a even number, (7) formule is used.

$$
\begin{aligned}
& Q_{\text {medyan }}=Q_{(N+1) / 2} \\
& Q_{\text {medyan }}=\left(Q_{N / 2}+Q_{(N+2) / 2}\right) / 2
\end{aligned}
$$

The founded Median value, is tested with t- test, $95 \%$ confidence bounds by using nonparametric method which Sen suggested. (Bai, 2014)

\subsection{Linear Regression}

The regression analysis is a technique that characterises the relation between two or more factor who has a cause effect relation, by estimating about the subject for the purpose of to be able to estimate with a mathematical method which calls regression model. In linear Regression formula;

$$
y=a+b x
$$

A gives the direction of factors $\&$ amount. Positive a means increasing factor; negative a means decreasing factor. Of a is closer to 0 , it means there is no difference. Linear trends significance is detected with student-t test. (Bayazit, 1995)

\subsection{Spearman's Rho}

Spearman Rho test is a nonparametric test. It is used to search the existence of linear trend and to determined existence of correlation between two observation series . The order statistics is determined by line up of $\mathrm{R}\left(x_{i}\right)$ observation from greater to lesser or the opposite $\&$ the value calculated with (10) formula.

$x_{i}(i=1,2,3, \ldots, n)$ values are Equal contingent range. On condition that observationseries $\mathrm{X}=\left(x_{1}, x_{2}, \ldots, x_{n}\right)$ vector; according to twoway tested $H_{0}$ hypothesis. The spearman Rho coefficient of correlation rs is calculated as;

$$
r_{s}=1-6\left[\sum_{i=1}^{n}\left(R\left(x_{i}\right)-i\right)^{2}\right] /\left(n^{3}-n\right)
$$

$\mathrm{R}\left(x_{i}\right)$, I is sequence number of observation, $\mathrm{i}$ isdatas observation sequence number is total observation number. $\mathrm{R}$ is test statistics $\mathrm{Z}$ value is calculated with (11) formula.

$$
z=r_{s} \sqrt{n-1}
$$

If in a selected significance level, $|\mathrm{z}|$ value is greater than $\mathrm{Za}$ that is selected in standard normal distribution table, Ho hypothesis that its based on observation? Values doesn't change, is rejected and concluded to existence of a trend.

\section{Results and Discussion}

Likely the most common approach is to prediction trends by linear regression (Solow, 1987). Such parametric methods exigency the variable to be normally distributed(Plantico et al., 1990; Cooter and LeDuc, 1995; Huth, 1999). In order to avoid disadvantages of the parametric methods, nonparametric approaches such as Mann-Kendall, Sen and Spearman's Rho testsare employed in this study.In this study, the time series of annual and monthly mean temperatures are analyzed in order to identify meaningful long-term trends for Aegean Region in Turkey.

Linear Regression analysis, Mann-Kendall, Sen' slope and Spearman's Rho tests was made of the value of annual and monthly temperature and summarized in Figure 2... The values $\pm 1.96(\approx \pm 2)$ of the test are statistically significant at $95 \%$ confidence level.

According to Linear Regression statistically significant (\%5 risk) increasing trend are found for annual temperature in all stations except Nazilli, Bornova and Ödemiş stations in Aegean region.In the annual temperature data, the significant trend wasn't found at the Nazilli, Bornova, Ödemiş, Manisa ve Emirdağ stations; but the significant increasing trend was found at the another all stations for Mann-Kendall and Sen's Methods. According to Spearman Rho, statistically significant increasing trend are found for annual temperature in all stations except Didim and Yatagan stations in Aegean region.

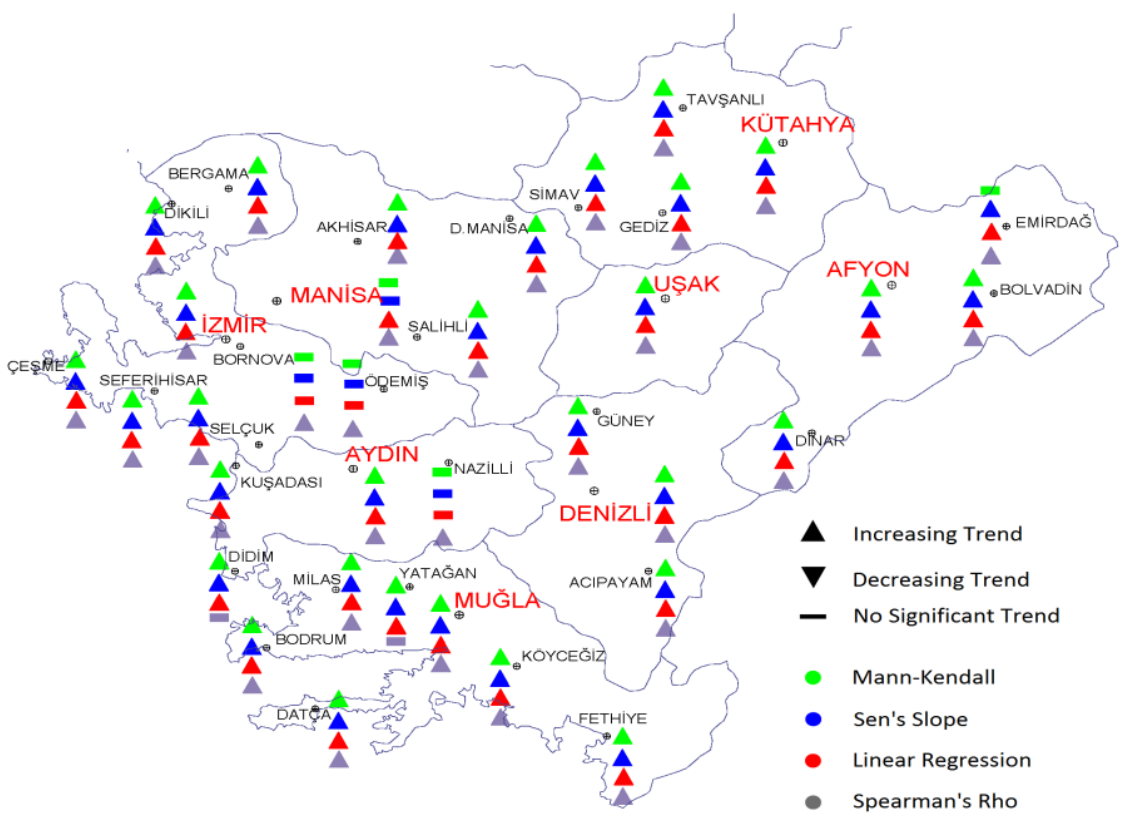

Figure 2: Annual trend analysis results of temperature for study area

Volume 6 Issue 7, July 2017 www.ijsr.net 


\section{International Journal of Science and Research (IJSR) \\ ISSN (Online): 2319-7064}

Index Copernicus Value (2015): 78.96 | Impact Factor (2015): 6.391

In the January monthly temperature data, the significant trend wasn't found at all stations expect Milas station. But the significant increasing trend was found in Milas stations according to Linear Regression, Mann-Kendall, Sen's and Spearman Rho Methods (Figure 3).

In the February month temperature data, the significant trend wasn't observed at all stations expect Demirci Manisa station. But the significant increasing trend was observed in Demirci Manisa stations according to Linear Regression, Mann-Kendall, Sen's Methods (Figure 3). According to Spearman Rho, statistically significant trend was not found for in this month in all stations.

In the March month temperature data, the significant trend wasn't observed at all stations expect Demirci Manisa and Bergama station. But the significant increasing trend was observed in Demirci Manisa and Bergama stations according to Mann-Kendall, Sen's Methods (Figure 3). In Linear Regression analysis, significant increasing trend was observed in Demirci Manisa, Bergama, Didim, Kuşadası and Manisa stations; the significant trend wasn't observed in another stations. According to Spearman Rho, the significant increasing trend was observed in Demirci Manisa, Bergama, Bodrum, Didim, Kuşadası, Manisa and Selçuk stations; but the statistically significant trend was not found for in this month in another stations.

In the April monthly temperature data, the significant trend wasn't found at all stations expect some station. But the significant increasing trend was found in Bolvadin, Çeşme, Datça, Kuşadası, Milas and Selçuk stations according to Mann-Kendall and Sen's Methods (Figure 3). According to Linear Regression analysis, the significant increasing trend was found in Bolvadin, Didim, Milas and Selçuk stations. According to Spearman Rho analysis, the significant increasing trend was found in Bolvadin, Çeşme, Datça, Denizli, Kuşadası, Milas, Selçuk and Seferihisar stations.

In the May monthly temperature data, the significant increasing trend was found at all stations expect some station for all methods. The significant trend wasn't found in Bolvadin, Bornova, Demirci Manisa, Didim, Emirdağ, Fethiye, Gediz, Köyceğiz, Muğla, Ödemiş, Salihli, Tavşanlı and Yatağan stations according to Mann-Kendall Methods (Figure 3). According to Sen Analysis, the significant trend wasn't found in Bolvadin, Bornova, Demirci Manisa, Didim, Emirdağ, Fethiye, Gediz, Köyceğiz, Muğla, Ödemiş, Salihli, Tavşanlı and Yatağan stations. According to Spearman Rho analysis, the significant increasing trend wasn't found in Bolvadin, Demirci Manisa, Didim, Emirdağ, Fethiye, Gediz, Köyceğiz, Ödemiş, Tavşanlı, ve Yatağan stations. According to Linear Regression analysis, the significant increasing trend was found in Afyon, Akhisar, Aydın, Bergama, Bodrum, Bolvadin, Çeşme, Datça, Denizli, Dikili, Dinar, İzmir, Kuşadası, Kütahya, Manisa, Milas, Seferihisar, Selçuk, Simav ve Uşak stations. The significant trend wasn’t found in another stations.

In the Jun month temperature data, the significant increasing trend was found at all stations expect Demirci Manisa and Didim stations for all methods (Figure 3).
In the July month temperature data, the significant increasing trend was found at all stations expect Didim station for all methods (Figure 3).

In the August month temperature data, the significant increasing trend was found at all stations expect Demirci Manisa and Didim station for Mann-Kendall and Sen Methods (Figure 3).According to Linear Regression analysis, the significant increasing trend was found in another stations except Muğla and Uşak stations. According to Spearman Rho analysis, the significant increasing trend was found in all stations.

In the September month temperature data, the significant trend wasn't observed at Aydın, Bornova, Demirci Manisa, Dinar, Emirdağ, Fethiye, Gediz, Kütahya, Manisa, Muğla, Ödemiş, Sinav, Tavşanlı and Uşak stations. But the significant increasing trend was observed in another stations according to Mann-Kendall Methods (Figure 3).The significant trend wasn't observed at Aydin, Bornova, Demirci Manisa, Dinar, Emirdağ, Fethiye, Gediz, Kütahya, Manisa, Muğla, Ödemiş, Sinav, Tavşanlı and Uşak stations. But the significant increasing trend was observed in another stations according to Sen's Methods (Figure 3).In Linear Regression analysis, significant trend wasn't observed in Aydın, Bornova, Demirci Manisa, Dikili, Emirdağ, Fethiye, Kütahya, Manisa, Muğla, Nazilli, Ödemiş, Sinav, Tavşanlı and Uşak stations; the significant increasing trend was observed in another stations. According to Spearman Rho, the significant trend wasn't observed in Aydın, Bornova, Dinar, Emirdağ, Fethiye, Gediz, Kütahya, Muğla, Ödemiş and Uşak stations; but the statistically significant increasing trend was found for in this month in another stations.

In the October month temperature data, the significant increasing trend was observed at Bodrum, Datça, Kuşadası, Milas, Salihli and Selçuk stations. But the significant trend wasn't observed in another stations according to MannKendall and Sen's Methods (Figure 3).In Linear Regression analysis, significant increasing trend was observed in Bodrum, Çeşme, Datça, Denizli, Kuşadası, Milas, Salihli and Selçuk stations; the significant trend wasn't observed in another stations. According to Spearman Rho, the significant increasing trend was observed in Afyon, Akhisar, Bergama, Bodrum, Bolvadin, Çeşme, Datça, Denizli, Kuşadası, Milas, Ödemiş, Seferihisar and Selçuk stations; but the statistically significant trend was not found for in this month in another stations.

In the November month temperature data, the significant decreasing trend was observed at Nazilli stations. But the significant trend wasn't observed in another stations according to Mann-Kendall and Sen's Methods (Figure 3). In Linear Regression analysis, significant increasing trend was observed in Demirci Manisa and Nazilli stations; the significant trend wasn't observed in another stations. According to Spearman Rho, the significant increasing trend was observed in Acıpayam, Demirci Manisa, Gediz, Milas, Seferihisar and Yatağan stations; but the statistically significant trend was not found for in this month in another stations. 


\section{International Journal of Science and Research (IJSR) \\ ISSN (Online): 2319-7064 \\ Index Copernicus Value (2015): 78.96 | Impact Factor (2015): 6.391}

In the December month temperature data, the significant decreasing trend was observed at Nazilli station; the significant increasing trend was observed at Demirci Manisa stations. But the significant trend wasn't observed in another stations according to Mann-Kendall and Sen's Methods (Figure 3). In Linear Regression analysis, significant increasing trend was observed in Demirci Manisa and
Nazilli stations; the significant trend wasn't observed in another stations. According to Spearman Rho, the significant increasing trend was observed in Demirci Manisa and Seferihisar stations; but the statistically significant trend was not found for in this month in another stations.

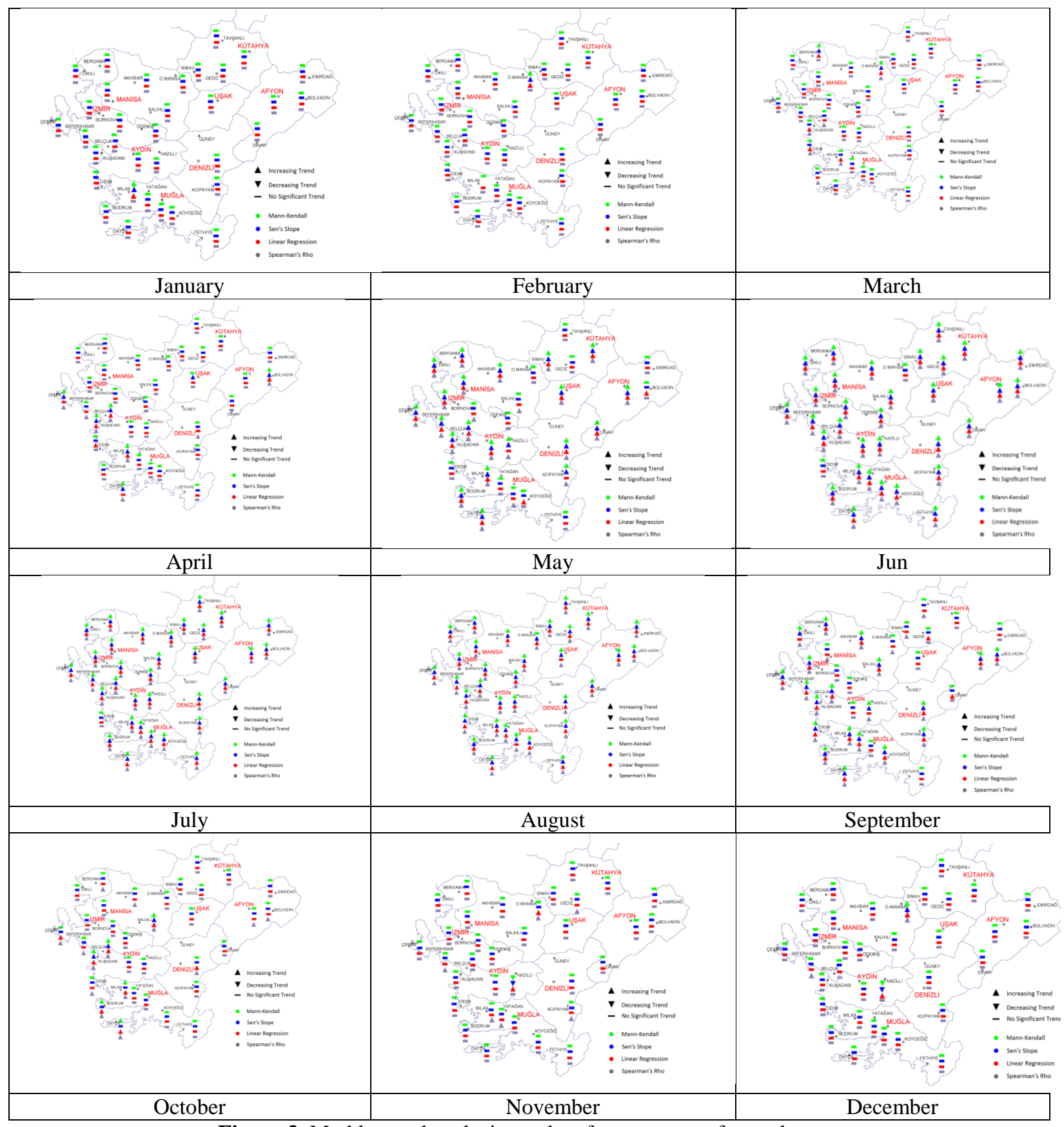

Figure 3. Mothly trend analysis results of temperature for study area

\section{Conclusion}

Trend analysis is one of the basic procedures to identify climate change effects on hydro-meteorological records. Four of the often used trend analysis methods are the Linear Regression, Mann-Kendall, Sen's and Spearman Rho methods.In this study was to analyze annual and monthly temperature trends in selected stations in the Aegean region of Turkey for the minimum 50 yearly period. The application of the Linear Regression, Mann-Kendall, Sen's and Spearman Rho methods is presented. Generally, the statistically significant increasing trend in the annual temperature data was found at the all stations for all methods. But only the statistically significant trend wasn't found in Ödemiş, Bornova, Nazilli, Emirdağ and Manisa stations according to Mann-Kendall and Sen's Methods; Nazilli, Bornova and Ödemiş stations according to Linear Regression Method; Didim and Yatagan stations according to Spearman Rho Method.

\section{Volume 6 Issue 7, July 2017} www.ijsr.net 


\section{International Journal of Science and Research (IJSR) \\ ISSN (Online): 2319-7064 \\ Index Copernicus Value (2015): 78.96 | Impact Factor (2015): 6.391}

In the January, February, March and April monthly temperature data, the significant trend wasn't found at all stations expect one station for all methods. Only in the March and April monthly temperature data increasing trend was found six stations. The analysis results are similar.The average temperature analysis showed an increasing trend in the remaining stations expect 11 stations in May. In this analysis showed an increase tendency in general except 2 stations in June. The reason of this, the data of these two stations is seen as there is less data than the other stations.In the July and August monthly temperature data, the significant increasing trend was found at all stations expect one station for all methods.In September, the increasing trend in coastal areas continues, whereas the increase in the internal regions left the trending region.In the average temperature analysis of October, 6 stations showed an upward tendency in general, while the other stations did not show a significant trend. In November and December the average temperature analysis left the effect of increasing tendency in general loss of significance.

Annual average temperature analyzes showed an increasing tendency in general, with an average trend of $85 \%$ in all methods.Monthly average temperature analyzes showed increasing temperature trends in May, June, July, August, September and October. In generaly, no significant trends have been observed outside of these months. The average rate of increase in ownership among these stations is $71 \%$.Results of the temperature data trend show a general increasing trend. This results were indicator of effects of climate change and drought in Aegean Region. After the operating, managing and planning of water resources in the region should be taken into consideration of this effects of climate change and drought.

\section{Acknowledge}

This work was supported by Scientific Research Project Coordination Unit of Pamukkale University. Project number: 2016FEBE009

\section{References}

[1] Almazroui M, Islam MN, Jones PD. 2014. Trends of temperature extremes in Saudi Arabia.International Journal of Climatology 34: 808-826.

[2] Bacanli UG, 2011. Dryness Characterization: A Climatic Water Deficit Approach In Turkey.Fresenius Environmental Bulletin20/3: 665-677.

[3] Bai Y, Xu Z, Zhang J, Mao D, Luo C, He Y, Liang G, Lu B, Bisesi MS, Sun Q, Xu X, Yang W, Liu Q, 2014. Regional impact of climate on Japanese encephalitis in areas located near the three gorges dam. Plos One. 9:1. doi: 10.1371/journal.pone.0084326

[4] Bayazıt M,Oğuz EB,1995. Mühendisler İçin İstatistik.Birsen Yayınevi.

[5] Cooter EJ, Leduc SK, 1995. Recent frost date trends in the north-eastern USA. International Journal of Climatology 15(1): 65-75.

[6] DMI (State Meteorological Service) http://www.dmi.gov.tr.
[7] Erinç S,1957. Tatbiki Klimatoloji ve Türkiye'nin İklim Şartları. İstanbul: İ.T.Ü. Hidrojeoloji Enstitüsü Yayınları Sayı:2, Teknik Üniversite Matbaası.

[8] Friedli HH, Lotscher H, Oeschger H, Siegenthaler U and Stauver B, 1986. Ice core record of the $13 \mathrm{C} / 12 \mathrm{C}$ ratio of atmospheric $\mathrm{CO} 2$ in the past two centuries. Nature 324:237-238.

[9] Huth R,1999. Statistical downscaling in central Europe: evaluation of methods and potential predictor. Climate Research 13(2): 1572-1616.

[10] Houghton JT, Meira Filho LG, Callander BA, Harris N, Kattenberg A, 1995. Climate Change 1995.The Science of Climate Change. Cambridge University Press: Cambridge.Jhajharia D, Dinpashoh Y, Kahya E, Choudhary RRand Singh VP, 2013. Trends in temperature over Godavari River basin in Southern Peninsular India. International Journal of Climatology, 34/5: 1369-1384.

[11] Kadioglu M,1997. Trends Surface Air Temperature Data Over Turkey. International Journal of Climatology, 17: 511-520.

[12] Karl TR, Knight RW, Gallo KP, Peterson TC, Jones PD, Kukla G, Plummer N, Razuvayev V, Lindseay J and Charlson RJ, 1993. A new perspective on recent global warming: Asymmetric trends of daily maximum and minimum temperature. Bulletin of the American Meteorological Society 74/6: 1007-1023.

[13] KrugerAC, Sekele SS, 2012. Trends in extreme temperature indices in South Africa: 1962 - 2009. International Journal of Climatology 33/3:661-676.

[14] Kruger AC, Shongwe S, 2004. Temperature Trends In South Africa : 1960 - 2003.International Journal of Climatology 24: 1929-1945.

[15] Longobardi A, Villani P, 2010. Trend analysis of annual and seasonal rainfall time series in the Mediterranean area.International Journal of Climatology30: 1538 1546.

[16] Lorius C, Jouzel D, Raynaud D, Hansen J, Le Treut H, 1990. The ice-core record: climate sensitivity and future greenhouse warming. Nature. 347: 139-144.

[17]Panda DK, Kumar A, 2014. The changing characteristics of monsoon rainfall in India during 1971 - 2005 and links with large scale circulation. Internatıonal Journal of Climatology 34/15: 3881-3899.

[18] Safeeq M, Mair A, Fares A,2013. Temporal and spatial trends in air temperature on the Island of Oahu , Hawaii. International Journal of Climatology33/13: 2816-2835

[19] Martinez MD, Serra C, Burgueno A, Lana X, 2010. Time trends of daily maximum and minimum temperatures in Catalonia ( ne Spain ) for the period 1975 - 2004. International Journal of Climatology. 30: 267-290.

[20] Viola F, Liuzzo L, Noto LV, Conti FL, Loggia GL, 2014. Spatial distribution of temperature trends in Sicily. International Journal of Climatology, 34: 1-17

[21] Kendall MG, 1975. Rank Correlation Methods. 4th ed. Charles Griffin: London.

[22] MannHB, 1945. Non-parametric test against trend. Econometrica, 13: 245-259. 


\section{International Journal of Science and Research (IJSR) \\ ISSN (Online): 2319-7064}

Index Copernicus Value (2015): 78.96 | Impact Factor (2015): 6.391

[23] Plantico MS,Karl TR, Kukla G,Gavin J, 1990. Is recent climate change across the United States related to rising levels of anthropogenic greenhouse gases?Journal of Geophysical Research Atmospheres 95: 16617-16637.

[24] SenPK, 1968. Estimates of the Regression Coefficient Based on Kendall's Tau. Journal of the American Statistical Association63/324: 1379-1389.

[25] Solow AR, 1987. Testing for Climate Change: An Application of the Two-Phase Regression Model. Journal of Climate and Applied Meteorology 26: 14011405.

Volume 6 Issue 7, July 2017 www.ijsr.net 